\title{
Biocompatibility Evaluation Criteria for Novel Xenograft Materials: Distribution and Quantification of Remnant Nucleic Acid and Alpha-Gal Epitope
}

\author{
Naso Filippo ${ }^{1 *}$, Aguiari Paola1, Iop Laura1, Spina Michele ${ }^{2}$ and Gerosa Gino1 \\ ${ }^{1}$ Department of Cardiac, Thoracic and Vascular Sciences, University of Padua, Padua - 35128, Italy \\ ${ }^{2}$ Departmennt of Experimental Biomedical Sciences, University of Padua, Padua - 35131, Italy
}

\begin{abstract}
Objective: Commercially decellularized xenogeneic scaffolds are currently employed as for the healing of diseased tissues. Strangely enough their use is permitted even in absence of any assessment of the elimination of xenogeneic cell material, as the alpha-Gal epitopes. In addition, the decellularization procedures are not monitored to prove the elimination of the calcific potential associated to the nucleic acids remnants. The currently treatment with glutaraldehyde is unable to grant a complete immuno-tolerance of implanted xenogeneic tissues, reducing but not eliminating the immunogenicity particularly for the alpha-Gal epitope (the major hindrance for the success of xenotransplantation). Recently, our group has extensively reported studies focused on the evaluation of biocompatibility properties of xenogeneic tissues. In this report we are performing this investigation and nucleic acid detection to novel xenogeneic tissues that have shown very promising preclinical/clinical results in different areas of application.
\end{abstract}

Methods: The alpha-Gal quantification was conducted by an ELISA test previously developed and patented by our research team which involves the use of the monoclonal anti apha-Gal antibody M86. Immunofluorescence analysis was performed for the visual distribution of both xenogeneic epitopes and nucleic acids residues. Finally for the total DNA quantification a commercially available kit was adopted.

Results: While the amount and distribution of the alpha-Gal epitopes was found different between the investigated biomaterials, the presence of nucleic acid remnants has been revealed as common feature, even in those tissues delivered as acellular by the manufacturer.

Conclusion: Insufficient quantitative evaluations performed at preclinical level about the residual content of xenogeneic epitopes, detergents and nucleic acid materials in scaffolds have led to disappointing and disastrous results. The risk of these dramatic accidents reoccurring remains very high unless safety parameters, among which the complete removal of major xenogeneic determinants (alpha-Gal) and calcification-prone nucleic acid residues, are identified and introduced in manufacturing practices.

Keywords: Biocompatibility; Bioprosthesis; Xenotransplantation; Antigenicity; Biological scaffold; Alpha-Gal; Tissue engineering

\section{Introduction}

Due to the ageing of human populations, the number of elderly patients suffering from chronic diseases or end-stage organ failure is constantly increasing. Physicians treat organ or tissue loss by transplanting organs from a compatible individual (homotransplantation) performing surgical reconstruction or using mechanical or bioprosthetic devices. Unfortunately, the request for organ and tissue (heart, kidney, lung, pancreas, cardiac valves, cartilage, etc...) far exceeds the number of available donors (Table 1). Additionally tissue substitutes have demonstrated a limited durability (heart valve substitutes, ligament and tendons, cartilage) and artificial prosthetic devices may badly affect patient's quality of life (VADS, pacemaker, hemo-dialysis, etc.).

The lack of homologous substitutes has led biomedical researchers to explore the use of animal donors as an attractive and unlimited source of biological devices (xenotransplantation). Scaffolds derived from mammalian tissues have been used to repair or replace a variety of damaged or diseased tissues including cardiac $[1,2]$, esophageal $[3,4]$, dermal [5], musculotendinous [6,7] and ocular [8], among others. Results of preclinical and clinical studies have varied from success [911] to complete failure [12-17]. The host response to these materials can depend on several aspects such as the original species (e.g. porcine, equine, bovine, fish), the tissue from which the extracellular matrix (ECM) has been isolated (e.g., dermis, small intestine, pericardium, cornea), the mechanical loading, the onset of biologic reaction and the effects of trophic factors to which the scaffold is exposed following implantation and host blood perfusion. Moreover, tissue treatment and decontamination/sterilization methods applied during manufacturing process can also markedly affect remodelling and functional outcome.

In order to produce biological devices intended for clinical use, xenogeneic donor tissues are usually subjected to decellularization procedures able to remove the resident cellular component, comprising

*Corresponding author: Filippo Naso, Department of Cardiac, Thoracic and Vascular Sciences, Biomedical Center "Pietro d'Abano", Via G.Orus 2B - 35122 Padua, Italy, Tel: +39.320.111.60.88; E-mail: m.zotarelli@gmail.com

Received November 29, 2013; Accepted December 24, 2013; Published December 26, 2013

Citation: Filippo N, Paola A, Laura I, Michele S, Gino G (2013) Biocompatibility Evaluation Criteria for Novel Xenograft Materials: Distribution and Quantification of Remnant Nucleic Acid and Alpha-Gal Epitope. J Stem Cell Res Ther S6: 009. doi:10.4172/2157-7633.S6-009

Copyright: $\odot 2013$ Filippo N, et al. This is an open-access article distributed under the terms of the Creative Commons Attribution License, which permits unrestricted use, distribution, and reproduction in any medium, provided the original author and source are credited. 
antigens and remnants of nucleic acids. Such treatments are commonly based on the use, under controlled conditions, of physical agents, detergents, enzymes and/or chemicals compounds with minimal or limited effects on architecture, ultrastructure, mechanical integrity and biological activity of the residual ECM scaffolds. However some of these treatments have been unable to completely remove remnants of cellular material such as nucleic acids and membrane fragments [18-23]. Such residues, entrapped among the ECM network, are able to activate innate and acquired immune reaction, and lead to acute failure of the implanted graft with subsequent fibrosis, scarring and encapsulation, up to the establishment of a chronic inflammatory reaction [24]. DNA remnants have been advocated as the main cause of "inflammatory reaction" and calcification phenomena (due to the presence of charged phosphoric acid ester groups) following the implantation of xenograft-derived scaffolds in orthopaedic or cardiac applications $[12,25]$. Notwithstanding the effort to completely eliminate each single whole-structured cell [26], antigenic determinants may persist in membrane residues and still be capable of reacting (e.g. the xenoantigen alpha-Gal considered the major hindrance for the success of xenotransplantation) [15,27]. This sugar moiety is expressed in most mammalian tissues, excluding humans and higher primates [28]. In humans, continuous antigenic stimulation by the gastrointestinal flora results in production of anti alpha-Gal antibodies accounting for $1 \%$ of the circulating immunoglobulins, both IgMs and IgAs $[29,30]$. Once a xenogenic tissue is recognized, the complement cascade is activated triggering endothelial cell dysfunction, platelet aggregation and vascular thrombosis [31].

The most common approach to preservation and manufacturing of bioprosthetic substitutes (pericardial tissue patches, biological heart valves prostheses, ligaments and tendons) is glutaraldehyde (GLU) fixation. GLU treatment has been considered, for more than 30 years, as the standard chemical process able to ensure tissue biocompatibility, increasing mechanical strength and allowing sterilization and safe storage of heart valve bioprostheses. Unfortunately, GLU fixation does not provide the complete masking of all xenoantigens, in particular the alpha-Gal epitope [32,33], eliciting an anti-aGal specific IgM immunoresponse once the bioprosthetic substitute is implanted in humans [34].

Over the last four years, our group has developed a solid experience on assessing the biocompatibility of xenogeneic tissues, based on the quantification and distribution of such xenogeneic epitope $[26,31,35]$. Accordingly we have investigated the content and distribution of alphaGal as well as of nucleic acid in a variety of novel xenogeneic tissues used or intended for use in clinical practice, that have shown very promising outcomes in different areas of application. The investigated tissues were derived from different animal species and were subjected to different manufacturing procedure. Producer and characteristics of the tested materials are reported in Table 2 .

\section{Materials and Methods}

All procedures and manipulation of tissues were always carried out in sterile conditions. From each type of tissue 10 samples were obtained for the alpha-Gal quantification, 3 samples for the immunofluorescence assay and 4 samples for the total DNA purification and quantification.

\section{Tuna cornea samples collection}

Six tuna cornea (TC) were directly removed from six freshly caught Atlantic Bluefin and placed in sterile cold phosphate buffered saline (PBS, Sigma, St. Louis, USA) in the presence of a full complement antibiotic solution (Penicillin $100 \mathrm{U} / \mathrm{ml}$, Streptomycin $100 \mathrm{mg} / \mathrm{ml}$ and Amphotericin B $250 \mu \mathrm{g} / \mathrm{ml}$ ) during transport to the laboratory. All blood residues were removed by sterile PBS washing and samples preserved in $0.3 \%$ GLU solution for 12 hours. Tuna cornea fixation was performed according to the technique described by Parravicini et al. [36]. To prevent folds, the specimens were inserted and locked inside a frame, and immersed in $0.2 \mathrm{M}$ acetate buffer $(\mathrm{pH}, 4.6)$ with $0.3 \%$ of GLU for 15 days. The corneal material was then treated for 24 hours with the same acetate buffer in $4 \%$ formaldehyde solution, for sterilization and removal of residual fixative traces.

\section{CorMatrix samples collection}

Samples of CorMatrix ${ }^{\mathbb{E}} \mathrm{ECM}^{\mathrm{TM}}$ for cardiac tissue repair have been provided by SIC System (Italian distributor). Three decellularized SISECM sheets $(7 \mathrm{~cm} \times 10 \mathrm{~cm})$, each from a different product lot, were extracted from their packaging and placed in phosphate buffered saline (PBS), $\mathrm{pH} 7.4$ at room temperature for 25 minutes to allow proper rehydration as required by the "Instruction for Use" provided by the manufacturer.

\section{Equine pericardium samples collection}

Two equine pericardial (EP) patches model XAG-400 (Edwards Lifesciences, Irvine, USA) treated with GLU were extracted from their packaging and subjected to three consecutive washes with sterile phosphate buffered saline (PBS), $\mathrm{pH} 7.4$ at room temperature for 4 minutes to remove the excess of the preserved solution as required by the "Instruction for Use" provided by the manufacturer.

\begin{tabular}{|l|l|l|}
\hline & $\begin{array}{l}\text { Number of Italian patients awaiting organ transplant for the year } \\
\mathbf{2 0 1 1}\end{array}$ & $\begin{array}{l}\text { Number of Italian patients who have undergone organ replacement for the } \\
\text { year } \mathbf{2 0 1 1}\end{array}$ \\
\hline Kidney & 6.594 & 1.539 \\
\hline Heart & 733 & 276 \\
\hline Lung & 382 & 119 \\
\hline Pancreas & 238 & 58 \\
\hline
\end{tabular}

Table 1: Data obtained from the Italian National Transplantation Centre.

\begin{tabular}{|l|l|l|}
\hline Manufacturer & Model & Features \\
\hline CorMatrix Cariovascular, Inc. & CorMatrix ${ }^{\circledR}$ ECM $^{\mathrm{TM}}$ & $\begin{array}{l}\text { Acellular scaffold derived from porcine small intestinal } \\
\text { submucosae }\end{array}$ \\
\hline $\begin{array}{l}\text { Udwards. FDA } \\
\text { European CE Mark }\end{array}$ \\
\hline $\begin{array}{l}\text { Biomaterial was manipulated according to the report of Parravicini } \\
\text { and colleagues [37] }\end{array}$ & XAG-400 & Glutaraldehyde-fixed equine pericardial patch \\
\hline---- & Glutaraldehyde-fixed tuna cornea \\
\hline
\end{tabular}

Table 2: Features and manufacture informations of the different analyzed tissues. 
Citation: Filippo N, Paola A, Laura I, Michele S, Gino G (2013) Biocompatibility Evaluation Criteria for Novel Xenograft Materials: Distribution and Quantification of Remnant Nucleic Acid and Alpha-Gal Epitope. J Stem Cell Res Ther S6: 009. doi:10.4172/2157-7633.S6-009

Page 3 of 8

\section{Alpha-Gal ELISA test: tissue preparation}

Each sample from TC, SIS and EP, was gently blotted on special filter paper (Whatman International Ltd, Maidstone, England) and its weight recorded (weight range 30-50 mg). As previously reported by our group [35], the GLU fixation procedure performed on the TC and EP samples is responsible for aspecific interaction between the epitopes and the antibody used for their detection. In order to avoid such confounding results, previously GLU-treated, TC and EP tissues were subjected to a "GLU inactivation procedures" actually under patent (European Application no. EP13154536.0), before performing the ELISA test. Conversely, SIS does not require such processing because supplied by the manufacturer as decellularized tissue not treated with GLU.

Subsequently, specimens were further minced and incubated with the primary anti-alpha-Gal antibody M86 (Axxora, Nottingham, UK) [1:50] for 2 hours at $37^{\circ} \mathrm{C}$ with gentle stirring and finally centrifuged at $14,340 \mathrm{~g}$ for 30 minutes at $4^{\circ} \mathrm{C}$.

\section{Alpha-Gal ELISA test}

The adopted ELISA test is briefly outlined [31]. A Polisorp 96 well plate (Nunc, Rochester, NY), was coated with $50 \mu \mathrm{l}$ of alpha-Gal/ BSA (Bovine Serum Albumine - Dextra Laboratories, UK), $5 \mu \mathrm{g} / \mathrm{ml}$, for 2 hours at $37^{\circ} \mathrm{C}$. After washing three times with PBS, the blocking procedure was performed using $250 \mu \mathrm{l}$ per well of $1 \%$ HSA (Human Serum Albumine - Sigma, St. Louis, USA) in PBS for 2 hours at room temperature in darkness; then wells were washed three times as above.

A set of wells was incubated with $100 \mu$ lof supernatant derived from the different samples (TC, SIS and EP) overnight at $4^{\circ} \mathrm{C}$ in darkness. After washing, the secondary HRP-conjugate antibody [1:500] (Dako Cytomation, Denmark) was loaded. Finally, $100 \mu \mathrm{l}$ of horseradish peroxidase substrate buffer (phosphate-cutrate buffer with sodium perborate plus o-phenylenediamine; Sigma, St. Louis, USA) was added to each well for 30 minutes at room temperature in darkness. The plate absorbance was measured by Titertek Multiskan Plus plate reader at $450 \mathrm{~nm}$.

\section{Immunofluorescence assay}

Tissues were embedded in OCT Compound (a solution of watersoluble glycols and resins, providing a convenient specimen matrix for cryostat sectioning, eliminating undesirable background staining, Tissue Tek ${ }^{\circledR}$, Tokyo, Japan) and, after cryocooling in isopentan and vapour of liquid nitrogen, $5-\mu \mathrm{m}$ cryosections were obtained. After "GLU inactivation procedure" carried out on TC and EP slices, a double staining with M86 monoclonal antibody [1:10] and 4',6-diamidino2-phenylindole (DAPI - Sigma, St. Louis, USA) was performed. Recognition of M86 was carried out by goat anti-mouse AlexaFluor 594 secondary antibody [1:100] (Molecular Probes, Carlsbad, CA). Images were acquired by DM 6000CS Leica microscope.

\section{Total DNA determination}

Samples (weight range 15-20 mg) were processed for total DNA extraction and purification by the DNaesy Blood \& Tissue Kit (Qiagen, Texas, USA). Briefly, samples are first lysed using proteinase K (Qiagen, Texas, USA). The lysate is loaded onto minispin column and buffer was previously adjusted to provide ideal DNA-binding conditions. During centrifugation, DNA is selectively bound to the DNeasy membrane as contaminants pass through. Remaining contaminants and enzyme inhibitors are removed in two wash steps and DNA is then eluted in buffer. The subsequently quantification was performed by a NanoDrop 1000 Spectrophotometer (Thermo Scientific, Delaware, USA).

\section{Statistical analysis}

Data are expressed as mean \pm SD. Significance of the differences between samples of the same or from different sheets were determined by one way ANOVA. Differences were considered statistically significant when $\mathrm{p}<0.05$.

\section{Results}

\section{Alpha-Gal ELISA test}

As reported in Table 3, the ELISA test did not reveal the presence of alpha-Gal xenogeneic epitopes within the TC and SIS samples tissue. Conversely the GLU-fixed EP samples showed an average amount of $9.7 \pm 4.9 \times 10^{10}$ epitopes each $10 \mathrm{mg}$ of wet weight $(\mathrm{n}=10, p>0.05)$.

\section{Immunofluorescence analysis}

The presence of the alpha-Gal epitopes in EP tissue was confirmed also by immunfluorescence analysis (Figure 3 ). At lower magnification (Figures 3A and 3C) the epitope distribution seems to be limited to the endothelial layer, while it resulted to be present in high amount also in the inner stroma as evidenced in Figure 3B. TC and SIS tissues did not exhibit alpha-Gal residues, confirming the data previously obtained by the ELISA test. As shown in Figures 1 and 2, the lack of any red fluorescent signals is a clear indication of the absence of alpha$\mathrm{Gal}$ in this tissue. A diffuse distribution of nucleic acids material was a common observation for all the analyzed tissues, as confirmed by DAPI

\begin{tabular}{|c|c|c|}
\hline \multicolumn{3}{|c|}{ Alpha-Gal content expressed as number of epitopes $/ 10 \mathrm{mg}$ of wet weight tissue } \\
\hline Equine pericardium & Tuna cornea & Porcine small intestinal submucosae \\
\hline $9.7 \pm 4.9 \times 1010$ & Not revealed & Not revealed \\
\hline
\end{tabular}

Table 3: Alpha-Gal content expressed as number of epitopes per $10 \mathrm{mg}$ of we tissue weight ( $n=10$ for each type of sample).

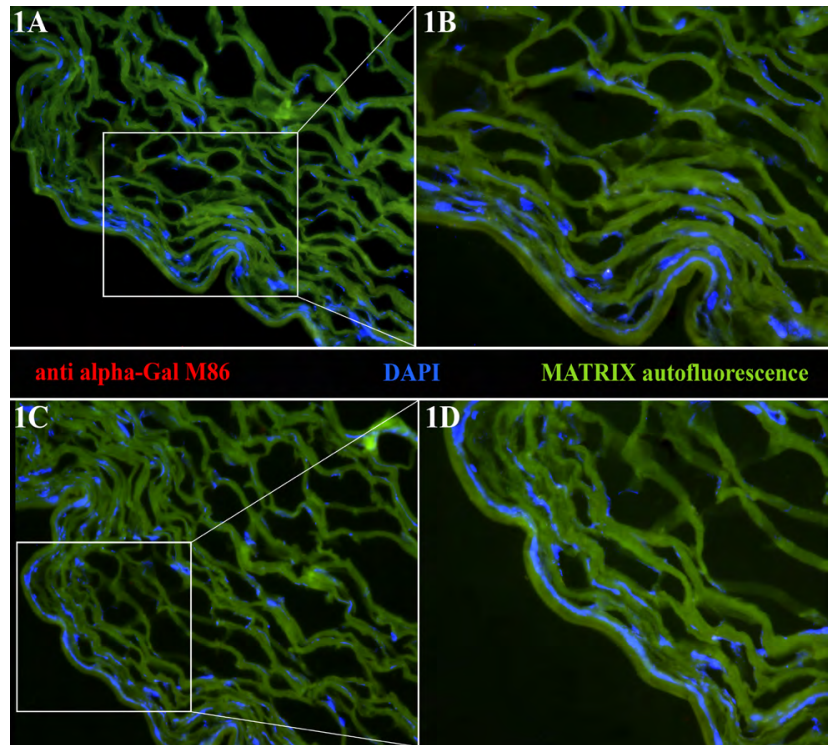

Figure 1: Alpha-Gal epitope distribution in two different samples (A-B and C-D) of glutaraldehyde-fixed tuna cornea material by immunofluorescence analysis. Magnification $20 \times$ for A and C; magnification $40 \times$ for B and D. Antialpha-Gal monoclonal antibody M86 - red; Nucleic acid material - blue; Matrix autofluorescence - green. 
Citation: Filippo N, Paola A, Laura I, Michele S, Gino G (2013) Biocompatibility Evaluation Criteria for Novel Xenograft Materials: Distribution and Quantification of Remnant Nucleic Acid and Alpha-Gal Epitope. J Stem Cell Res Ther S6: 009. doi:10.4172/2157-7633.S6-009

Page 4 of 8
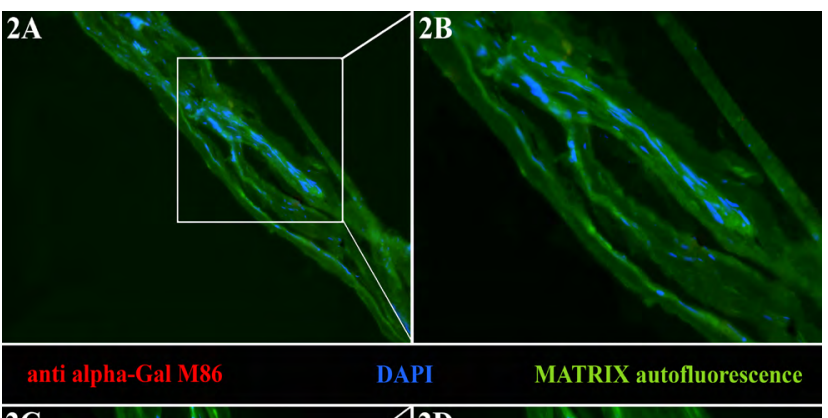

MATRIX autofluorescence
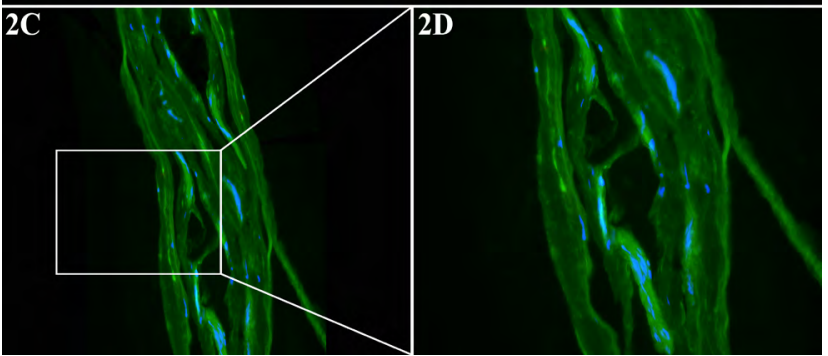

Figure 2: Alpha-Gal epitope distribution in two different samples (A-B and C-D) of decellularized CorMatrix SIS-ECM material by immunofluorescence analysis. Note the presence of nucleic acid remnants in the declared acellular scaffold. Magnification $20 \times$ for $A$ and C; magnification $40 \times$ for B and D. Antialpha-Gal monoclonal antibody M86 - red; Nucleic acid material - blue; Matrix autofluorescence - green.

staining. This finding was unexpected in the SIS-ECM sample (Figure 2) because provided as decellularized tissue by the manufacturer.

\section{Total DNA determination}

Despite SIS-ECM was previously subjected to decellularizing procedures, the average amount of total DNA content, was similar to GLU-fixed TC specimens: $6.64 \pm 1.34 \mu \mathrm{g}$ and $6.20 \pm 0.74 \mu \mathrm{g} / 10 \mathrm{mg}$ of wet tissue respectively (Figure 4). A greater amount, $15.30 \pm 1.61 \mu \mathrm{g} / 10$ mg, was exhibited by EP. Differences between samples of the same tissue were not statistically significant $(p>0.05)$.

\section{Discussion}

\section{Tuna cornea}

TC has several intrinsic characteristics that make it suitable for bioapplication such as its strength, size, ready availability and histologic composition. Previous results of physical tests indicated that TC stroma features biomechanical characteristics similar to those of bovine pericardium already in use for bioprosthetic heart valve manufacturing [36]. These functional properties, combined with low antigenicity [37], make TC a potential biomaterial for the production of heart valve substitute as well as tissue patches. However the presence of the alphaGal gene in ocular surface tissue could be decisive for the rejection of the implanted xenograft [38]. Up to now, a qualitative evaluation of such xenoantigen in corneal tissue has been limited to three fish species [39-41]: our results implement this knowledge. In fact the low antigenic profile of TC is determined by the complete absence of the alpha-Gal epitope as confirmed by our performed immunofluorescence analysis (Figure 1) and ELISA test (Table 3). While the lack of such antigen ensures a better biocompatibility, the widespread presence of the nucleic acids material in the GLU-treated biomaterial, will expose the same tissue to a high probability of calcification occurrences similarly to the current biological heart valve substitutes [42] (even if these latter maintain a considerable amount of alpha-Gal epitope able to react with circulating human antibodies [35]). The low amount of DNA content revealed in the tissue (Figure 2) is justified by its low cell density which characterizing this type of matrix. These results are likely to explain, at least in part, the excellent in-vivo and in-vitro results reported by the use of this tissue as a material for heart valve substitute manufacturing [36]. Otherwise, the implant performed in a sheep model by Parravicini R et al. [36] does not appears considerably representative for the evaluation of the calcific potential of this biomaterial due to the insufficient follow up (6 months).

\section{CorMatrix $^{\mathrm{TM}}$ ECM}

Features like a great level of graft resorption and remodelling, an high content of trophic factors as well as an excellent biomechanical behaviour (very similar to that of glutaraldehyde treated bovine pericardial tissue) [43], have identified the acellular porcine SIS-ECM as an optimal source of material to manufacture cardiovascular biological devices. SIS-ECM has been shown to promote cells attachment and proliferation (epidermal cells, fibroblast [44], smooth muscle cells [45], cardiomyocytes and myofibroblasts [46]), recruitment of mononuclear cells with an M2 phenotype [24] and graft vascularization [47]. However, to meet the requirements of optimal biocompatibility, a proper decellularization treatment could lead to a non-thrombogenic alpha-Gal epitope-free acellular scaffolds, able to potentially avoid inflammatory and calcification phenomena. A previous report by McPherson and colleagues clearly confirmed the recognition of the aGal epitope in porcine SIS, and its prompt binding with human IgG [48]. Both the ELISA test (Table 3) and the immunofluorescence analysis (Figure 1) performed in this study highlight as the decellularization treatment devised by CorMatrix ${ }^{\mathbb{E}} \mathrm{ECM}^{\mathrm{TM}}$ is able to achieve the elimination of the resident xenogeneic alpha-Gal antigens. While the alpha-Gal-free feature can be considered as a indication of good decellularization treatment (thus confirming also the removal of the residues of cell membranes), the large amount of nucleic acids


Figure 3: Alpha-Gal epitope distribution in two different samples (A-B and $C-D$ ) of glutaraldehyde-fixed equine pericardial patch material by immunofluorescence analysis. Magnification 20x for A and C; magnification 40x for B and D. Anti-alpha-Gal monoclonal antibody M86 - red; Nucleic acid material - blue; Matrix autofluorescence - green. 



Figure 4: DNA content expressed as $\mu \mathrm{g} / 10 \mathrm{mg}$ per wet tissue weight in CorMatrix ${ }^{\circledR}$ SIS-ECM (A), tuna cornea (B) and equine pericardial patch (C). Ten different samples were analyzed for each tissue (open bar) and mean value \pm SD is represented by the filled grey bar. For all tissues the differences within the single specimen (samples 1-10) was not resulted statistically significant $(p>0.05)$. 
debris found within the CorMatrix ${ }^{\circledR} \mathrm{ECM}^{\mathrm{TM}}$ should be considered alarming, as liable for potential initiation of the calcification process $[15,25]$. The porcine acellular CorMatrix ${ }^{\mathbb{R}} \mathrm{ECM}^{\mathrm{TM}}$ has been shown to maintain an average DNA amount $(6.96 \pm 1.6 \mu \mathrm{g} / 10 \mathrm{mg})$ equal to half of that originally present in a porcine native tissue $(11.48 \pm 2.4 \mu \mathrm{g} / 10$ $\mathrm{mg}$ ) [49]. These DNA residues, spreading throughout the thickness of the SIS-ECM tissue (Figure 1), are likely prone to calcify as observed in acellular SIS-ECM graft covering the internal side of porcine pulmonary valved stents [45]. Similar results were reported also by Zheng MH et al. [12] and Walton JR et al. [14] for whome porcine SIS membranes (Restore ${ }^{\mathrm{TM}}$ SIS, US-FDA clearance) failed to repair human rotator cuff: histological examination revealed that the xenograft material was not a cell-free collagenous matrix but contained a multiple cell layers [12] and DNA [14]. Finally, the incomplete biomaterial inertness seems to be another cause of failure for porcine SIS (SurgiSIS, Cook Inc.) in alloplastic esophageal replacement [13]. An investigation addressed to evaluate if such relevant residual DNA remnants could comprise endogenous retrovirus sequences, as previously found in acellular porcine heart valve scaffolds [50], is still in progress. Further studies are performing in order to assess how these nucleic residues can be correlated to the failure of the SIS-derived material in high-strain environments [51].

\section{Equine pericardium}

EP xenograft patch is a relatively new product employed in various medical fields such as musculoskeletal, neurological and cardiovascular surgery [52-58]. It has also been described for use in repair of rotator cuff defects $[59,60]$, as well as for the treatment of diabetic foot ulcers [61]. Finally patch of EP tissue were applied either for the coverage [17] or for the self-made manufacture of heart valves substitutes [62]. Like many of the xenogeneic tissues intended for clinical use, even the EP patches are supplied after GLU fixation.

While GLU treatment is the most commonly used crosslinking agent able to reduce tissue degradation and to preserve anatomic integrity, strength and flexibility, it represent also a potential calcific factor especially when the tissue is subjected to a high mechanical stress. In fact, the attempt to reconstruct arterial vessels or tendons with an EP patch, showed no positive results in condition of increasing blood pressure or mechanical loading. As evidenced by Yamamoto $\mathrm{H}$ and colleagues, dilatation of the EP tube graft did develop as a result of long-term exposure to arterial pressure [63]. Similarly, degeneration of an EP valve conduit was occurred much earlier than that of the standard bovine or porcine bioprosthetic heart valve substitutes (at 3 to 5 years after the intervention), with a constant increase of the pressure gradient across the conduit during the follow up [64].

The treatment with GLU, in addition, was not efficient to ensure a complete immunotolerance of the implanted xenogeneic tissue, reducing but not eliminating the alpha-Gal immunogenicity. Noteworthy, the immune response against these xenogeneic residues has been recognized, together with the presence of nucleic acids materials, as an additional factor leading to tissue mineralization [32]. The amount of available and reactive alpha-Gal epitope evaluated in EP patch resulted in our investigation to be $15 \%$ higher than in commercially bovine heart valve substitute [35]. In a hypothetical biocompatibility classification, this assessment puts the EP tissue well behind the bovine and porcine pericardium for high pressure cardiovascular and orthopaedic purposes. Conversely good results were obtained for venous conduits reconstruction [65], treatment of diabetic foot wounds [62] and tympanic perforation [66].

\section{Conclusions}

Commercially available decellularized SIS and GLU-fixed EP materials are currently employed for the treatment of several tissue damages sequelae in humans (sometime with questionable results), even in the absence of any publicly disclosed quantitative/qualitative assessment concerning the retention and the elimination of alphaGal xenogeneic epitopes. Likewise, the decellularization treatment is not monitored enough to grant the reduction of the calcific potential associated to the nucleic acid remnants retained within the matrix. Now a day there is a growing consensus about the strong relationship linking the failure of bioprosthetic grafts provoked by calcific occurrence and immunologic reactions to the lack of a reliable control tool providing quantitative information about the undesirable remainings within a tissue engineered scaffold before its clinical use. The effective removal or coverage of both cellular components (including the xenogeneic epitopes express in the cellular membrane residues) and nucleic acid materials debris should very likely become a benchmark for the future approvals of biomaterials intended for clinical use.

\section{Acknowledgements}

This research was supported by Fondazione Cassa di Risparmio di Padova e Rovigo (Italian Heart Project).

The authors declare no competing financial or general conflict of interests.

\section{References}

1. Akhyari $P$, Kamiya $H$, Haverich $A$, Karck M, Lichtenberg A (2008) Myocardial tissue engineering: the extracellular matrix. Eur J Cardiothorac Surg 34: 229241.

2. Badylak SF, Kochupura PV, Cohen IS, Doronin SV, Saltman AE, et al (2006) The use of extracellular matrix as an inductive scaffold for the partial replacement of functional myocardium. Cell Transplant 15: S29-40.

3. Nieponice A, Gilbert TW, Badylak SF (2006) Reinforcement of esophagea anastomoses with an extracellular matrix scaffold in a canine model. Ann Thorac Surg 82: 2050-2058.

4. Nieponice A, McGrath K, Qureshi I, Beckman EJ, Luketich JD, et al. (2009) An extracellular matrix scaffold for esophageal stricture prevention after circumferential EMR. Gastrointest Endosc 69: 289-296.

5. Brigido SA, Boc SF, Lopez RC (2004) Effective management of major lower extremity wounds using an acellular regenerative tissue matrix: a pilot study. Orthopedics 27: S145e149.

6. Snyder SJ, Arnoczky SP, Bond JL, Dopirak R (2009) Histologic evaluation of a biopsy specimen obtained 3 months after rotator cuff augmentation with GraftJacket Matrix. Arthroscopy 25: 329-333.

7. Valentin JE, Turner NJ, Gilbert TW, Badylak SF (2010) Functional skeletal muscle formation with a biologic scaffold. Biomaterials 31: 7475-7484.

8. Yoeruek E, Bayyoud T, Maurus C, Hofmann J, Spitzer MS, et al. (2012) Decellularization of porcine corneas and repopulation with human corneal cells for tissue-engineered xenografts. Acta Ophthalmol 90: e125-131.

9. Ayyildiz A, Akgül KT, Huri E, Nuhoğlu B, Kiliçoğlu B, et al. (2008) Use of porcine small intestinal submucosa in bladder augmentation in rabbit: longterm histological outcome. ANZ J Surg 78: 82-86.

10. Adams JE, Zobitz ME, Reach JS, An KN, Steinmann SP (2006) Rotator cuff repair using an acellular dermal matrix graft: an in vivo study in a canine model. Arthroscopy 22: 700-709.

11. Badylak SF, Hoppo T, Nieponice A, Gilbert TW, Davison JM, et al. (2011) Esophageal preservation in five male patients after endoscopic inner-layer circumferential resection in the setting of superficial cancer: a regenerative medicine approach with a biologic scaffold. Tissue Eng Part A 17: 1643-1650.

12. Zheng MH, Chen J, Kirilak Y, Willers C, Xu J, et al. (2005) Porcine small intestine submucosa (SIS) is not an acellular collagenous matrix and contains porcine DNA: possible implications in human implantation. J Biomed Mater Res B Appl Biomater 73: 61-67. 
Citation: Filippo N, Paola A, Laura I, Michele S, Gino G (2013) Biocompatibility Evaluation Criteria for Novel Xenograft Materials: Distribution and Quantification of Remnant Nucleic Acid and Alpha-Gal Epitope. J Stem Cell Res Ther S6: 009. doi:10.4172/2157-7633.S6-009

13. Doede T, Bondartschuk M, Joerck C, Schulze E, Goernig M (2009) Unsuccessful alloplastic esophageal replacement with porcine small intestinal submucosa. Artif Organs 33: 328-333.

14. Walton JR, Bowman NK, Khatib Y, Linklater J, Murrell GA (2007) Restore orthobiologic implant: not recommended for augmentation of rotator cuff repairs. J Bone Joint Surg Am 89A: 786-791.

15. Simon P, Kasimir MT, Seebacher G, Weigel G, Ullrich R, et al. (2003) Early failure of the tissue engineered porcine heart valve SYNERGRAFT in pediatric patients. Eur J Cardiothorac Surg 23: 1002-1006.

16. Spark JI, Yeluri S, Derham C, Wong YT, Leitch D (2008) Incomplete cellular depopulation may explain the high failure rate of bovine ureteric grafts. $\mathrm{Br} J$ Surg 95: 582-585.

17. Rüffer A, Purbojo A, Cicha I, Glöckler M, Potapov S, et al. (2010) Early failure of xenogenous de-cellularised pulmonary valve conduits--a word of caution! Eur J Cardiothorac Surg 38: 78-85.

18. Gilbert TW, Freund JM, Badylak SF (2009) Quantification of DNA in biologic scaffold materials. J Surg Res 152: 135-139.

19. Gilbert TW, Sellaro TL, Badilak SF (2006) Decellularization of tissues and organs. Biomaterials 27: 3675-3683.

20. Arai S, Orton EC (2009) Immunoblot detection of soluble protein antigens from sodium dodecyl sulfate- and sodium deoxycholate-treated candidate bioscaffold tissues. J Heart Valve Dis 18: 439-443.

21. Böer U, Lohrenz A, Klingenberg M, Pich A, Haverich A, et al. (2011) The effect of detergent-based decellularization procedures on cellular proteins and immunogenicity in equine carotid artery grafts. Biomaterials 32: 9730-9737.

22. Bastian F, Stelzmüller ME, Kratochwill K, Kasimir MT, Simon P, et al. (2008) IgG deposition and activation of the classical complement pathway involvement in the activation of human granulocytes by decellularized porcine heart valve tissue. Biomaterials 29: 1824-1832.

23. Kasimir MT, Rieder E, Seebacher G, Nigisch A, Dekan B, et al. (2006) Decellularization does not eliminate thrombogenicity and inflammatory stimulation in tissue-engineered porcine heart valves. J Heart Valve Dis 15 278-286.

24. Badylak SF, Gilbert TW (2008) Immune response to biologic scaffold materials Semin Immunol 20: 109-116.

25. Spina M, Ortolani F, El Messlemani A, Gandaglia A, Bujan J, et al. (2003) Isolation of intact aortic valve scaffolds for heart-valve bioprostheses: extracellular matrix structure, prevention from calcification, and cell repopulation features. J Biomed Mater Res A 67: 1338-1350.

26. Naso F, Gandaglia A, Iop L, Spina M, Gerosa G (2012) Alpha-Gal detectors in xenotransplantation research: a word of caution. Xenotransplantation 19: 215 220.

27. Park CS, Park SS, Choi SY, Yoon SH, Kim WH, et al. (2010) Anti alphaGal Immune response following porcine bioprosthesis implantation in children. $J$ Heart Valve Disease 19: 124-130.

28. Macher BA, Galili U (2008) The Galalpha1,3Galbeta1,4GIcNAc-R (alpha-Gal) epitope: a carbohydrate of unique evolution and clinical relevance. Biochim Biophys Acta 1780: 75-88.

29. Galili U (2005) The alpha-gal epitope and the anti-Gal antibody in xenotransplantation and in cancer immunotherapy. Immunol Cell Biol 83: 674 686

30. Rieben R, Bovin NV, Korchagina EY, Oriol R, Nifant'ev NE, et al. (2000) Xenotransplantation: in vitro analysis of synthetic alpha-galactosyl inhibitors of human anti-Galalpha1-->3Gal IgM and IgG antibodies. Glycobiology 10: 141148.

31. Naso F, Gandaglia A, lop L, Spina M, Gerosa G (2011) First quantitative assay of alpha-Gal in soft tissues: presence and distribution of the epitope before and after cell removal from xenogeneic heart valves. Acta Biomater 7: 1728-1734.

32. Konakci KZ, Bohle B, Blumer R, Hoetzenecker W, Roth G, et al. (2005) AlphaGal on bioprostheses: xenograft immune response in cardiac surgery. Eur $J$ Clin Invest 35: 17-23.

33. Bloch O, Golde P, Dohmen PM, Posner S, Konertz W, et al. (2011) Immune response in patients receiving a bioprosthetic heart valve: lack of response with decellularized valves. Tissue Eng Part A 17: 2399-2405.
34. Mangold A, Szerafin T, Hoetzenecker K, Hacker S, Lichtenauer M, et al. (2009) Alpha-Gal specific IgG immune response after implantation of bioprostheses. Thorac Cardiovasc Surg 57: 191-195

35. Naso F, Gandaglia A, Bottio T, Tarzia V, Nottle MB, et al. (2013) First quantification of alpha-Gal epitope in current glutaraldehyde-fixed heart valve bioprostheses. Xenotransplantation 20: 252-261.

36. Parravicini R, Cocconcelli F, Verona A, Parravicini V, Giuliani E, et al. (2012) Tuna cornea as biomaterial for cardiac applications. Tex Heart Inst J 39: 179183

37. Guerraty M, Mohler III ER (2007) Models of aortic valve calcification. J Investig Med 55: 278-283.

38. Yoeruek E, Bayyoud T, Maurus C, Hofmann J, Spitzer MS, et al. (2012) Decellularization of porcine corneas and repopulation with human corneal cells for tissue-engineered xenografts. Acta Ophthalmol 90: e125-131.

39. Shao Y, Yu Y, Pei CG, Qu Y, Gao GP, et al. (2012) The expression and distribution of $\alpha-G a l$ gene in various species ocular surface tissue. Int $J$ Ophthalmol 5: 543-548.

40. Lee HI, Kim MK, Oh JY, Ko JH, Lee HJ, et al. (2007) Gal alpha (1-3) Ga expression of the cornea, and in xenotransplantation. Xenotransplantation 14 612-618.

41. Eckhardt AE, Goldstein IJ (1983) Isolation and characterization of a family of alpha-D-galactosyl-containing glycopeptides from Ehrlich ascites tumor cells. Biochemistry 22: 5290-5297.

42. Rapoport HS, Connolly JM, Fulmer J, Dai N, Murti BH, et al. (2007) Mechanisms of the in vivo inhibition of calcification of bioprosthetic porcine aortic valve cusps and aortic wall with triglycidylamine/mercapto biphosphonate. Biomaterials 28 : 690-699.

43. Sacks MS, Gloeckner DC (1999) Quantification of the fiber architecture and biaxial mechanical behavior of porcine intestinal submucosa. J Biomed Mater Res 46: 1-10.

44. Badylak SF, Record R, Lindberg K, Hodde J, Park K (1998) Small intestinal submucosa: a substrate for in vitro cell growth. J Biomater Sci Polym Ed 9 863-878.

45. Metzner A, Stock UA, lino K, Fischer G, Huemme T, et al. (2010) Percutaneous pulmonary valve replacement: autologous tissue-engineered valved stents. Cardiovasc Res 88: 453-461.

46. Zhao ZQ, Puskas JD, Xu D, Wang NP, Mosunjac M, et al. (2010) Improvement in cardiac function with small intestine extracellular matrix is associated with recruitment of C-kit cells, myofibroblasts, and macrophages after myocardial infarction. J Am Coll Cardiol 55: 1250-1261.

47. Crapo PM, Wang Y (2010) Small intestinal submucosa gel as a potentia scaffolding material for cardiac tissue engineering. Acta Biomater 6: 2091 2096.

48. McPherson TB, Liang H, Record RD, Badylak SF (2000) Galalpha(1,3)Gal epitope in porcine small intestinal submucosa. Tissue Eng 6: 233-239.

49. Qiagen Group (2006) Dneasy Blood and Tissue Handbook.

50. Leyh RG, Wilhelmi M, Walles T, Kallenbach K, Rebe P, et al. (2003) Acellularized porcine heart valve scaffolds for heart valve tissue engineering and the risk of cross-species transmission of porcine endogenous retrovirus. J Thoarc Cardiovasc Surg 126: 1000-1004.

51. Arnold GA, Mathews KG, Roe S, Mente P, Seaboch T (2009) Biomechanical comparison of four soft tissue replacement materials: an in vitro evaluation of single and multilaminate porcine small intestinal submucosa, canine fascia lata, and polypropylene mesh. Vet Surg 38: 834-844

52. Yamamoto H, Yamamoto F, Ishibashi K, Motokawa M (2009) In situ replacement with equine pericardial roll grafts for ruptured infected aneurysms of the abdominal aorta. J Vasc Surg 49: 1041-1045.

53. Sato H, Suzuki N, Baba T, Ueda T, Mawatari T, et al. (2008) Repair of ventricular septal perforation with asymmetrical conical patch exclusion. Ann Thorac Cardiovasc Surg 14: 192-195.

54. Von Segesser L, Cox J, Faidutti B (1986) Equine pericardial xenograft in orthotopic position: early results. Thorac Cardiovasc Surg 34: 35-38.

55. Von Segesser L, Jornod N, Faidutti B (1987) Repeat sternotomy after reconstruction of the pericardial sac with glutaraldehyde-preserved equine pericardium. J Thorac Cardiovasc Surg 93: 616-619. 
Citation: Filippo N, Paola A, Laura I, Michele S, Gino G (2013) Biocompatibility Evaluation Criteria for Novel Xenograft Materials: Distribution and Quantification of Remnant Nucleic Acid and Alpha-Gal Epitope. J Stem Cell Res Ther S6: 009. doi:10.4172/2157-7633.S6-009

Page 8 of 8

56. Iha K, Koja K, Kusaba A (1994) Morphological, immunohistological and fibrinolytic features of patch grafts for reconstruction of the inferior vena cava. Cardiovasc Surg 2: 592-597.

57. Noishiki Y, Takahashi K, Yamamoto K, Mo M, Matsumoto A, et al. (1994) A new cardiac wall substitute with high affinity for fibroblasts that can induce an endothelial cell lining. ASAIO J 40: M751-756.

58. Montinaro A, Gianfreda CD, Proto $P(2007)$ Equine pericardium for dural grafts: clinical results in 200 patients. J Neurosurg Sci 51: 17-19.

59. Coons DA, Alan Barber $F$ (2006) Tendon graft substitutesdrotator cuff patches. Sports Med Arthrosc 14: 185-190.

60. Aurora A, McCarron J, lannotti JP, Derwin K (2007) Commercially available extracellular matrix materials for rotator cuff repairs: state of the art and future trends. J Shoulder Elbow Surg 16: S171-178.

61. National Institutes of Health. ClinicalTrials.gov. The Mechanism of Action of the Unite Biomatrix in Diabetic Foot Ulcer.
62. Doss M, Martens S, Wood JP, Miskovic A, Christodoulou T, et al. (2005) Aortic leaflet replacement with the new $3 \mathrm{~F}$ stentless aortic bioprosthesis. Ann Thorac Surg 79: 682-685.

63. Yamamoto H, Yamamoto F, Ishibashi K, Chida Y, Minamiya Y, et al. (2009) In situ replacement of the thoracic aorta using an equine pericardial roll graft for an aortobronchial fistula due to aortic rupture. Gen Thorac Cardiovasc Surg 57: 413-417.

64. Ando M, Imai Y, Takanashi Y, Hoshino S, Seo K, et al. (1997) Fate of trileaflet equine pericardial extracardiac conduit used for the correction of anomalies having pulmonic ventricle-pulmonary arterial discontinuità. Ann Thorac Surg 64: 154-158.

65. Asai K, Watanabe M, Matsukiyo H, Osawa A, Saito T, et al. (2011) Combined hepatic resection with the inferior vena cava and diaphragm and reconstruction using an equine pericardial patch: report of a case. Surg Today 41: 1670-1673.

66. Albera R, Dagna F, Lacilla M, Canale A (2009) Equine versus bovine pericardium in transmeatal underlay myringoplasty. Ann Otol Rhinol Laryngol 118: $287-291$.
This article was originally published in a special issue, Transplantation Immunology handled by Editor(s). Qing Ma, University of Texas, USA 